\title{
PERJANJIAN SEWA GUNA USAHA ANTARA LESSEE DAN LESSOR
}

\section{Aprilianti}

Dosen Bagian Hukum Perdata Fakultas Hukum Universitas Lampung

\section{Abstrak}

Perjanjian sewa guna usaha (leasing) yang diadakan oleh Lessor dan Lesseen dilakukan secara tertulis dalam bentuk perjanjian standar. Isi perjanjian tersebut ditentukan oleh jenis dari leasing itu sendiri dan hubungan hukum (hak dan kewajiban) timbal balik antara Lessor dan Lessee. Bagi Lessor, hak dan kewajibannya adalah memperoleh pembayaran sebagai imbalan jasa dan menyerahkan barang modal kepada Lessee. Sedangkan hak dan kewajiban Lessee adalah meperoleh kegunaan dari barang modal dan membayar sewa secara berkala. Tidak dipenuhinya hak dan kewajiban masing-masing pihak maka dapat disebut wanprestasi. Perjanjian akan berakhir jika hak dan kewajiban Lessor dan Lessee telah dilaksanakan sesuai dengan perjanjian.

Kata Kunci: Leasing, Lessor, Lessee, hak dan kewajiban.

\section{PENDAHULUAN}

Kebutuhan dalam kehidupan memerlukan dana yang tidak sedikit, semakin tinggi tingkat kehidupan akan mempengaruhi meningkatnya kebutuhan akan dana. Dalam memenuhi kebutuhan dana tersebut, pihak swasta banyak menggunakan jasa lembaga perbankan. Akan tetapi ternyata lembaga perbankan tidak dapat memenuhi banyaknya kebutuhan dana dalam masyarakat. Hal ini mengingat keterbatasan jangkauan penyebaran kredit oleh lembaga perbankan, keterbatasan sumber dana dan keharusan memberlakukan prinsip-prinsip pemberian kredit yang sangat ketat. Masyarakat kemudian mencari bentuk-bentuk penyandang dana lain yang dapat memenuhi kebutuhan dana mereka. Salah satunya adalah dengan adanya lembaga sewa guna usaha (untuk selanjutnya disebut leasing) yang merupakan lembaga yang lebih fleksibel dibanding lembaga perbankan. Fleksibilitas lembaga ini dalam hal dokumen, jaminan, struktur kontrak, besar dan jangka waktu pembayaran cicilan oleh penyewa guna usaha dan prosedur yang sederhana.

Sewa guna usaha merupakan usaha dan lembaga dalam bentuk penyediaan barang modal baik secara finance lease maupun operating lease untuk digunakan oleh lessee sebagai pelaku usaha selama jangka waktu tertentu berdasarkan pembayaran secara berkala. Berdasarkan pengertian di atas dapat dilihat bahwa ada dua macam bentuk sewa guna usaha yaitu secara finance lease dengan hak opsi dan operating lease tanpa hak opsi. Sewa guna usaha melibatkan beberapa pihak seperti perusahaan sewa guna usaha (lessor), penyewa guna usaha (lessee) dan penyedia barang objek sewa guna usaha (supplier).

Lessor memberikan bantuan dalam hal pembiayaan barang modal bagi masyarakat terutama bagi 
pengusaha kecil yang ingin mengembangkan usahanya namun menemui kesulitan dalam hal pengadaan barang modal. Hampir semua bidang bisnis maupun non bisnis telah dimasuki oleh bisnis sewa guna usaha, seperti pada bidang transportasi, industri, konstruksi, kesehatan dan lain-lainnya. Sewa guna usaha merupakan alternatif sumber pembiayaan untuk memperoleh dana dalam pengadaan barang modal. Bidang usaha sewa guna usaha memberikan kemudahankemudahan dibandingkan dengan lembaga pembiayaan lain, seperti kemudahan dalam prosedur memperoleh pembiayaan, efisien waktu, pengaturan yang tidak rumit dan jaminan yang tidak memberatkan.

Kegiatan sewa guna usaha dapat terjadi diawali dengan adanya kebutuhan dari pihak lessee akan barang modal dan adanya keterbatasan dana sehingga muncul pihak lessor sebagai penyandang dana untuk membiayai pembelian barang tersebut lebih dahulu dari pihak supplier. Kemudian atas adanya pembelian barang tersebut oleh pihak lessor mengakibatkan pihak supplier harus bertanggung jawab menyerahkan barang tersebut kepada lessee dalam kondisi baik. Sedangkan pihak lessee berkewajiban membayar uang angsuran secara berkala untuk penggantian pembelian barang modal sesuai dengan jumlah yang telah ditetapkan oleh lessor.

Lessor dalam memberikan pembiayaan harus memiliki keyakinan bahwa lessee sanggup membayar cicilan sebagaimana mestinya, sehingga pihak lessor memerlukan data dan penelitian terlebih dahulu atas permohonan pembiayaan oleh lessee. Keyakinan lessor terhadap kemampuan lessee menerapkan prinsip $5 \mathrm{C}$, yang terdiri dari watak (Character), kemampuan (Capasity), kecukupan modal (Capital), kondisi ekonomi (Condition of Economy) dan jaminan (Collaterals).

Masyarakat yang membutuhkan pembiayaan ini harus terlebih dahulu menghubungi perusahaan pembiayaan tersebut. Kemudian antara lessor dan calon lessee mengadakan suatu perjanjian pembiayaan sewa guna usaha. Perjanjian ini membuat para pihak terikat dan menimbulkan hak dan kewajiban serta tanggung jawab bagi masing-masing pihak. Hak dan kewajiban dan tanggung jawab yang dimiliki pihak-pihak hanya terbatas pada apa yang sudah diperjanjikan sebelumnya. Apabila para pihak atau salah satu pihak melakukan hal-hal yang diluar dari apa yang telah diperjanjikan, maka terjadilah wanprestasi yang mengakibatkan kerugian bagi pihak yang melakukannya.

Jika tidak terjadi wanprestasi atau perjanjian tersebut berjalan sesuai dengan yang telah disepakati para pihak, maka perjanjian berakhir sesuai dengan yang diharapkan. Pada masa akhir perjanjian ini juga diberikan hak opsi kepada lessee, yaitu hak untuk membeli barang modal dengan melunasi pembayaran nilai sisa dan hak untuk memperpanjang jangka waktu perjanjian sewa guna usaha. Berdasarkan paparan di atas maka penulis bermaksud mengadakan kajian lebih mendalam tentang perjanjian sewa guna usaha antara lessor dan lessee. 


\section{PEMBAHASAN}

\subsection{Pengertian Sewa Guna Usaha}

Sewa guna usaha atau leasing berasal dari bahasa Inggris yaitu to lease yang artinya "menyewakan". Menurut Surat Keputusan (SK) Bersama Menkeu, Menteri Perindustrian dan Menteri Perdagangan Nomor N.KEP122/MK/ IV/2/1974, Nomor 32/M/SK/2/1974, Nomor 30/Kpb/1/1974 Tentang Perizinan Usaha Leasing, Pengertian Leasing adalah setiap kegiatan pembiayaan perusahaan dalam bentuk penyediaan barang-barang modal untuk digunakan oleh suatu perusahaan untuk suatu jangka waktu tertentu, berdasarkan pembayaranpembayaran secara berkala disertai dengan hak pilih (opsi) dari perusahaan tersebut untuk membeli barang-barang modal yang bersangkutan atau memperpanjang jangka waktu leasing berdasarkan nilai sisa yang telah disepakati bersama.

Menurut Kepmenkeu RI No. 1169/KMK.01/1991 Tentang Kegiatan Sewa Guna Usaha, Pasal 1 huruf a, leasing diartikan sebagai suatu kegiatan pembiayaan dalam bentuk penyediaan barang modal baik secara sewa guna usaha dengan hak opsi (finance lease) maupun sewa guna usaha tanpa hak opsi (operating lease) untuk dipergunakan oleh lessee selama jangka waktu berdasarkan pemabayan secara berkala.

Pengertian menurut Equipment Leasing Association, leasing adalah perjanjian antara lessor dan lessee untuk menyewa suatu jenis barang modal tertentu yang dipilih oleh lessee. Hak kepemilikan atas barang modal tersebut ada pada lessor sedangkan lessee hanya menggunakan barang modal tersebut berdasarkan pembayaran uang sewa yang telah ditentukan dalam jangka waktu tertentu.

Berdasarkan beberapa pengertian di atas maka terdapat beberapa unsur mengenai sewa guna usaha, yaitu:

a. Adanya suatu perusahaan pembiayaan (lessor);

b. Adanya calon penyewa guna usaha (lessee);

c. Penyediaan barang modal;

d. Keterbatasan jangka waktu;

e. Pembayaran secara berkala;

f. Hak opsi bagi lessee;

g. Ada nilai sisa (residu).

\subsection{Dasar Hukum Sewa Guna Usaha}

Sewa guna usaha memiliki dua dasar hukum, baik yang bersifat pokok maupun bersifat administrasi.

\section{a. Dasar Hukum Pokok Sewa Guna Usaha.}

Pasal 1338 KUHPdt merupakan dasar hukum pokok, karena dalam pasal ini diatur mengenai perikatan. Setiap perikatan yang dibuat pihak-pihak berlaku sebagai undang-undang bagi para pihak yang membuatnya. Pasal ini merupakan cerminan dari asas "kebebasan berkontrak". Asas ini mempunyai arti bahwa para pihak bebas membuat kontrak dan mengatur sendiri isi kontrak, sepanjang memenuhi ketentuan syarat sahnya perjanjian (Pasal 1320 KUHPdt), tidak dilarang oleh undang-undang, sesuai dengan kebiasaan yang berlaku,dilaksanakan dengan itikad baik. 


\section{b. Dasar Hukum bersifat Administratif,}

1. Keppres RI No.61 Tahun 1988 Tentang Lembaga Pembiayaan,

2. SKB tiga Menteri yang terdiri dari Menteri Keuangan, Menteri Perindustrian,

Menteri

Perdagangan No.Kep22/MK/IV/2/1974,

No.32/M/SK/2/1974 Tentang

Perizinan Usaha Leasing.

3. Keputusan Menteri Keuangan RI No.1251/KMK.013/1988

Tentang Ketentuan dan Tata cara Pelasanaan Lembaga Pembiayaan.

4. Keputusan Menteri Keuangan RI No.634/KMK.013/1990 Tentang Pengadaan Barang Modal Berfasilitas Melalui Perusahaan Sewa Guna Usaha (Leasing).

5. Keputusan Menteri Keuangan RI No.1169/KMK.01/1991 Tentang Kegiatan Sewa Guna Usaha (Leasing).

\subsection{Perjanjian Sewa Guna Usaha}

Perjanjian sewa guna usaha (lease agreement) yang dibuat pada umumnya sudah dalam bentuk standar yang dibuat oleh pihak lessor, sedangkan lessee hanya menyetujuinya saja. Perjanjian yang dibuat tersebut mengikat pihak-pihak yang membuatnya.

Berdasarkan

Keputusan

Menteri

Keuangan

No1169/KMK.01/1991 Pasal 9, isi perjanjian sewa guna usaha, sekurang-kurangnya memuat beberapa hal, antara lain:

a. jenis transaksi sewa guna usaha;

b. Nama dan alamat masing-masing pihak;

c. Nama, jenis, tipe dan lokasi penggunaan barang modal; d. Masa sewa guna usaha;

e. Opsi bagi lessee dalam hal transaksi sewa guna usaha;

f. Tanggungjawab para pihak atas barang modal yang menjadi objek sewa guna usaha;

g. Harga perolehan, nilai pembiayaan, pembayaran sewa guna usaha, angsuran pokok pembiayaan, imbalan jasa sewa guna usaha, nilai sisa, simpanan jaminan dan ketentuan asuransi atas barang modal yang disewa guna usahakan;

h. Ketentuan mengenai pengakhiran transaksi sewa guna usaha yang dipercepat dan penetapan kerugian yang harus ditanggung lessee dalam hal barang modal dengan hak opsi hilang, rusak atau tidak berfungsi karena sebab apapun.

Berdasarkan uraian di atas maka perjanjian sewa guna usaha mepunyai beberapa sifat, yaitu:

a. Konsensual yaitu perjanjian yang terjadi apabila para pihak-pihak tercapai kata sepakat dan kata sepakat itu mengenai barangbarang modal dan harganya, maksudnya perjanjian sewa guna usaha itu sudah lahir pada detik tercapainya kata sepakat mengenai jangka waktu kontrak dengan masa barang modal secara ekonomis dan harganya dibayar secara berkala;

b. Formal yaitu perjanjian yang didapat atas dasar persetujuan antara para pihak yang didasarkan pada kata sepakat yang dinyatakan dengan suatu akta tertulis, jadi dalam perjanjian sewa guna usaha selalu diikuti dengan surat perjanjian sewa guna usaha yang dibuat oleh lessor; 
c. Kekuatan mengikat dari perjanjian sewa guna usaha, yaitu perjanjian sewa guna usaha yang dibuat oleh lessor dan lessee secara sah berlaku seperti undang-undang dan mengikat mereka;

d. Asas kepribadian dari perjanjian sewa guna usaha, dalam hal ini mengandung hak dan kewajiban lessee dan lessor. Lessor mempunyai kewajiban menyerahkan barang modal, sedankan lessee memperoleh hak untuk memakai barang modal tersebut setelah ia memenuhi kewajibannya dalam perjanjian sewa guna usaha. Jadi, perjanjian sewa guna usaha hanya mengikat lessor dan lessee.

\subsection{Proses Terjadinya Perjanjian Sewa Guna Usaha}

\section{a. Tahap (sebelum perjanjian) \\ Pra-kontraktual terjadinya}

Pada tahap ini terdiri dari beberapa rangkaian kegiatan yang meliputi:

1) Negosiasi (tawar menawar), merupakan langkah awal yang terjadi antara calon lessee dengan supplier, dimana antara keduanya terjadi proses saling tawar menawar mengenai penentuan dan penawaran harga dan barang objek sewa guna usaha;

2) Konfirmasi (pemberitahuan), merupakan langkah lebih lanjut setelah pihak lessee dan supplier sepakat mengenai barang objek sewa guna usaha dan harganya, kemudian calon lessee mengajukan permohonan kepada pihak lessor untuk mendapatkan fasilitas pembiayaan sewa guna usaha. Pada tahap ini calon lessee diharuskan mengisi formulir permohonan yang telah disediakan oleh pihak lessor;

3) Evaluasi kelayakan, tahap pemeriksaan formulir permohonan, kelengkapan persyaratan, pengamatan secara langsung akan usaha dari calon lessee tersebut;

4) Keputusan, merupakan tahap dimana pihak lessor memberikan penilaian apakah fasilitas sewa guna usaha dapat diberikan atau tidak kepada calon lessee.

\section{b. Tahap Kontraktual (terjadinya perjanjian)}

Pada tahap ini merupakan rangkaian kegiatan penandatanganan perjanjian oleh pihak calon lessee dengan pihak lessor.

Penandatanganan perjanjian tersebut merupakan tanda bahwa calon lessee telah sepakat mengenai isi dari perjanjian standar yang telah dibuat oleh pihak lessor. Pada tahap ini kedua pihak telah sepakat untuk menjalankan hak dan kewajibannya masing-masing sesuai dengan isi perjanjian.

\subsection{Hak dan Kewajiban Para Pihak}

Pasal 1338 ayat (1) KUHPdt mengenai perjanjian berlaku sebagai undang-undang bagi pihak-pihak, berarti perjanjian tersebut mempunyai kekuatan mengikat dan memaksa serta memberi kepastian hukum bagi pihak-pihak yang membuatnya. Sehingga pihak-pihak harus mentaati perjanjian tersebut sama dengan mentaati undangundang atau dengan kata lain para pihak harus melaksanakan hak dan 
kewajiban yang terdapat dalam perjanjian dengan baik.

\section{a. Hak dan Kewajiban Lessee}

Hak pihak Lessee dalam perjanjian sewa guna usaha:

1) Memperoleh fasilitas pembiayaan sewa guna usaha dari pihak lessor untuk membiayai pembelian barang yang menjadi objek perjanjian sewa guna usaha. Terhadap barang tersebut kepemilikannya secara yuridis (legal owner) tetap dipegang oleh pihak lessor sedangkan pihak lessee hanya menguasai secara fisik (economic owner). Lessee dapat memperoleh hak milik atas barang tersebut setelah melunasi seluruh pembayaran sewa guna usaha dan menggunakan hak opsinya.

2) Menerima barang yang menjadi objek perjanjian dari supplier tepat waktu sesuai dengan waktu yang tertera dalam order pembelian.

3) Pada akhir masa kontrak, lessee dapat menggunakan hak opsinya.

Kewajiban pihak Lessee dalam perjanjian sewa guna usaha:

1) Membayar angsuran uang sewa guna usaha setiap bulannya dengan jumlah yang telah ditetapkan dan pada waktu yang telah ditentukan;

2) Mengasuransikan objek sewa guna usaha, baik lessee menunjuk sendiri perusahaan asuransinya atau menyerahkan pada pihak lessor;

3) Membayar nilai sisa pada saat menggunakan hak opsi untuk membeli barang objek sewa guna usaha;

4) Menyelenggarakan pembukuan yang telah diaudit oleh akuntan publik dan diserahkan kepada lessor.

\section{b. Hak dan Kewajiban Lessor}

Hak bagi Lessor dalam perjanjian sewa guna usaha:

1) Menerima pembayaran uang sewa guna usaha setiap bulannya dengan jumlah dan waktu yang telah ditetapkan;

2) Memegang bukti-bukti kepemilikan atas barang objek sewa guna usaha;

3) Memerintahkan lessee untuk membayar seluruh angsuran, menuntut pengembalian barang objek perjanjian dari lessee, mengakhiri perjanjian secara sepihak, jika terjadi hal dalam kejadian tertentu, misalnya karena kelalaian atas merosotnya harga barang, bangkrutnya usaha lessee, pihak lessee terlibat dalam perkara perdata atau pidana, barang ditelantarkan oleh lessee sehingga barang tersebut hilang atau rusak berat.

Kewajiban bagi lessor dalam perjanjian sewa guna usaha:

1) Memberikan pembiayaan pada lessee, yaitu dengan cara menyediakan dana dalam hal pembelian barang yang menjadi objek perjanjian.

2) Menyerahkan barang tepat waktu dengan menghubungi terlebih dahulu pihak supplier yang bersangkutan.

3) Menyerahkan bukti pemindahan kepemilikan barang objek perjanjian setelah lessee menggunakan hak opsinya untuk membeli. 


\subsection{Tanggung jawab Para Pihak}

Tanggung jawab pihak lessee, meliputi:

a. Pemakaian barang, lessee harus bertanggung jawab atas barang yang menjadi objek perjanjian dan mempergunakan barang tersebut dengan baik;

b. Perawatan barang, lessee memiliki tanggung jawab untuk mematuhi setiap anjuran dari supplier perihal penyimpanan dan perawatan barang;

c. Jika lessee mengetahui terdapat cacat yang terlihat atau tersembunyi pada barang objek perjanjian dan ia tidak segera melaporkan (7 hari setelah penyerahan barang) pada supplier maka lessee tetap bertanggungjawab untuk memenuhi kewajibannya sebagai pihak dalam perjanjian;

d. Lessee bertanggung jawab penuh atas risiko, kehilangan, kerusakan atau musnahnya barang karena sebab apapun juga kecuali akibat keadaan memaksa.

Tanggung jawab pihak lessor, meliputi:

a. Bertanggung jawab penuh atas pembayaran pembelian barang objek perjanjian kepada supplier setelah diterimanya surat penerimaan barang dan perintah untuk membayar;

b. Lessor juga bertanggung jawab untuk mengusahakan agar pihak supplier menyerahkan barang tepat waktu seperti yang tercantum dalam order pembelian.

\subsection{Penyelesaian Wanprestasi}

Wanprestasi pada prinsipnya merupakan salah satu keadaan dari tidak dilakukan atau tidak mampu melaksanakan perjanjian, disamping keadaan lain yaitu alpa atau lalai atau ingkar janji atau juga melanggar perjanjian, bila ia melakukan atau berbuat sesuatu yang tidak boleh dilakukannya. Dalam perjanjian sewa guna usaha, wanprestasi dapat saja terjadi jika:

a. Lessee lalai membayar sejumlah uang angsuran yang telah ditetapkan dalam perjanjian;

b. Lessee tidak melaksanakan kewajiban pembayaran biayabiaya serta ongkos-ongkos lain atau denda keterlambatan dalam tenggang waktu yang telah ditetapkan;

c. Lessee telah melakukan sesuatu yang dilarang dalam perjanjian, misalnya mengalihkan hak pada orang lain, menyewagunausahakan ulang, menggadaikan barang objek perjanjian.

Dalam hal lessee melakukan wanprestasi seperti tersebut di atas, maka tindakan yang dilakukan oleh lessor adalah dengan mengirim somasi (surat pemberitahuan) bahwa lessee harus memenuhi prestasi atau kewajiban yang tertunda pada tanggal yang telah ditetapkan dalam surat somasi tersebut.

Jika setelah diberi somasi, pihak lessee tidak juga melaksanakan kewajibannya atau tetap lalai untuk memenuhi prestasi, maka tindakan selanjutnya adalah menarik kembali barang modal yang menjadi objek sewa guna usaha dengan membebankan biaya penarikan kepada lessee dan dengan cara 
percepatan pengakhiran perjanjian sewa guna usaha yang mengakibatkan lessee harus memenuhi semua kewajiban atas ongkos-ongkos dan biaya lain yang dikenakan kepadanya. Akibatnya lessee kehilangan hak untuk menggunakan barang modal tersebut, bahkan pihak lessor dapat mengakhiri perjanjian secara sepihak dan segala biaya yang timbul akibat dari hal tersebut merupakan beban pihak lessee. Bila terjadi perselisihan antara lessee dan lessor biasanya diselesaikan melalui jalur musyawarah dan jalur hukum. Tetapi jalur hukum jarang digunakan oleh pihak-pihak.

\subsection{Berakhirnya Perjanjian Sewa Guna Usaha}

Pada perjanjian sewa guna usaha dapat berakhir karena 3 (tiga) hal, yaitu:

a. Kesepakatan, perjanjian dapat diakhiri kapan saja apabila para pihak telah sepakat Jika lessee menggunakan hak opsinya yaitu mengembalikan barang modal kepada lessor atau lessee membeli barang modal tersebut;

b. Telah terjadi wanprestasi (breanch of contract) salah satu pihak tidak melaksanakan prestasinya sesuai dengan kontrak;

c. Force Majeure, timbul suatu keadaan diluar kesalahan para pihak, sehingga perjanjian berakhir.

\section{PENUTUP}

Proses terjadinya perjanjian sewa guna usaha antara lessee dan lessor melalui proses tawar menawar (negosiasi), (konfirmasi), evaluasi kelayakan dan keputusan pemberian pembiayaan oleh lessor. Jika semua persyaratan telah lengkap maka dilakukan penandatanganan naskah perjanjian untuk kemudian dilaksanakan oleh pihak-pihak, pelaksanaan tersebut harus dilakukan dengan itikad baik.

Perjanjian sewa guna usaha pada umumnya mengacu pada perjanjian standar, dimana formulir perjanjiannya telah disediakan oleh pihak lessor, pihak lessee hanya tinggal menyetujuinya saja (take it or leave it). Akibat dari perjanjian standar tersebut hak dan kewajiban serta tanggung jawab dalam perjanjian lebih banyak dibebankan kepada pihak lessee.

Dalam pelaksanaannya jika terjadi wanprestasi dan timbul perselisihan maka ada 2 (dua) cara penyelesaiannya melalui musyawarah dan melalui jalur hukum, namun jalan musyawarah yang banyak dipilih oleh para pihak. Pada akhir perjanjian pihak lessee diberi hak opsi untuk mengembalikan barang modal atau membeli barang modal tersebut.

\section{DAFTAR PUSTAKA}

Andasasmita, Komar. 1993. Leasing (Teori dan Praktek). Cetakan I Ikatan Notaris Indonesia, Komisariat daerah Jawa Barat, Bandung.

Anwari, Achmad. 1887. Leasing di Indonesia. Ghalia Indonesia, Jakarta.

Bintang, Sanusi dan Dahlan. 2000. Pokok-Pokok Hukum Ekonomi dan Bisnis. PT Citra Aditya Bakti, Bandung. 
Eukadi, Eddy. P. 1990. Mekanisme Leasing. Cetakan kedua. Ghalia Indonesia, Jakarta.

Fuady, Munir. 1999. Hukum Pembiayaan Dalam Teori dan Praktek. Citra Aditya Bakti, Bandung.

Herawaty, Dian. 2002. Tinauan Yuridis Wanprestasi oleh Lessee Dalam Suatu Perjanjian Leasing. Skripsi. Universitas Lampung.

Muhammad, Abdulkadir dan Rilda Murniati. 2000. Lembaga Keuangan dan Pembiayaan. Citra Aditya Bakti, Bandung.

Simatupang. Richard Burton. 1996. Aspek Hukum Dalam Bisnis. Ineka Cipta. Jakarta.

Sunaryo. 2005. Hukum Lembaga Pembiayaan (Buku Ajar). FH Universitas Lampung.

Tunggal, Amin Widjaya dan Arif Djohan Tunggal. 1994. Aspek Yuridis Dalam Leasing. Cetakan I. Rineka Cipta, Jakarta.

Kitab Undang-Undang Hukum Perdata (Terjemahan R.Subekti, 1996. Pradnya Paramita).

Keputusan Presiden No.61 Tahun 1988 Tentang Lembaga Pembiayaan.

Keputusan Menteri Keuangan No.1251/KMK.013/1988

Tentang Ketentuan dan Tata Cara Pelaksanaan Lembaga Pembiayaan.

Keputusan Menteri Keuangan No.1169/KMK.01/1991 Tentang Sewa Guna Usaha. 